\title{
NEGOTIATION OF IDENTITY IN DIASPORIC LITERATURE: A CASE STUDY ON AMY TAN'S THE HUNDRED SECRET SENSES AND LESLIE MARMON SILKO'S CEREMONY
}

\author{
Ken Ruri Nindyasmara \\ nindyasmara.ken@gmail.com
}

\begin{abstract}
Negotiation of identity has become an important issue because its never-ending process always relates to conflicts, differences and similarities. Chinese Americans and Native Americans are two distinct diasporic communities amongst other ethnic group in the U.S. As minorities, they experience prejudice, discrimination and exclusion from mainstream American culture and society. This research aims to reveal the negotiation of identity of Chinese Americans and Native Americans which is reflected on their literature. Literature is seen as the record of diasporic experience of both ethnic groups.

This research is qualitative conducted under Post-Nationalist American Studies. Post-colonial, hegemony and representation theories are used to help the process of data analysis. The primary data is taken from The Hundred Secret Senses written by Amy Tan and Ceremony written by Leslie Marmon Silko. The secondary data are taken from books, journals, and internet sources.

The finding of the research shows that Chinese Americans and Native Americans negotiate their identity by choosing or combining competing values. The construction of identity is done through the reenactment of ethnic root and the adaptation to mainstream American cultural values. Sense of belongingness, history and socio-cultural background become the determining factors of identity negotiation. In brief, they construct hybrid identity to survive and to counter American hegemony. Compared to Native Americans, Chinese Americans are more blending to mainstream American culture. However, both novels depict their hybrid identity.
\end{abstract}

Keywords: identity negotiation, diasporic literature, diaspora communities, hegemony, hybrid identity

\section{Introduction}

The United States of America is one of many countries in the world with very heavy migration and diaspora issues, and even Kennedy (2008) stated that, "the USA is a country established by immigrants" (p. 1). Additionally, Bradbury \& Temperly (1998) explicated that, "America is a nation that is profoundly mixed ethnically, geographically, sociallysustained and changed by constant waves of immigration from an ever changing range of sources" (p. 20). In short, the USA is the meeting point of immigrants and diasporic communities from all over the world each having a social and cultural background. This statement marks that migration and diaspora issues have been deeply embedded in US society since the establishment of the nation.

Each diasporic community indeed has their own cultural products mirroring each identity, culture and experience, such as music, dance, literature and other works of art. Of those cultural products, it is diasporic literature that can easily be found in bookstores, libraries, or even on 
television. This literature can be studied to dig out immigrants' experiences. The question that can be raised is how can a literary work be regarded and studied to dig out the experience of diasporic societies if it is fiction? Although a literary work is considered fiction, it has mental facts that are developed from their thought. Their thought is without a doubt the product of what they experience as diasporic societies. Therefore, diasporic literature is the embodiment of diasporic societies' experiences and thought. Hence, the theme of diasporic literature usually lingers on the issues of immigration and diaspora themselves such as discrimination, cultural differences, stereotypes, struggle to gain success in American society, and identity negotiation. The literature itself mirrors a particular diasporic society experience. This study aims to reveal the negotiation of identity in two diasporic communities through their literature, particularly novels. The Hundred Secret Senses written by Amy Tan, a Chinese American and Ceremony written by Leslie Marmon Silko, a Native American, will be used as the objective materials of this research.

Chinese-Americans are one of many immigrant populations that seek their fortune in the U.S. Chinese-Americans represent the second largest racial minority group as well as the oldest AsianAmerican group in the U.S. The first waves of Chinese migrated to the U.S. in the early $18^{\text {th }}$ century "to make their fortune in the California Gold Rush" (Chang, 2004, p.4). However, their dreams were replaced with the reality of building the transcontinental railroad as indentured labors, as well as being victims of prejudice and discrimination because of their 'bizarre' physical features and odd cultural traditions. Being indentured labors receiving extremely small wages, it was impossible for them to return to China so they had to work hard to earn a living. However, Chinese diasporic communities nowadays have become one of the most successful immigrant communities in the United States so the term "model minority" (Chou \& Feagin, 2014, p.1) is attached to them.

While Chinese have been excluded and discriminated against in U.S. society, they have been able to survive and have become one of the most successful immigrant groups in the U.S.A. In contrast, there is a diasporic community which seems to be declining and never far from a poor and miserable life. That community is Native Americans. Since the European conquest, Native Americans have been victimized due to their culture and way of life which is considered primitive. It means that until today, Native Americans, despite their long tenure in America, are still the object of prejudice, discrimination and mockery. Moreover, their life in reservations today, with minor facilities and technology, makes them even more excluded from American society. They have become the forgotten, the "vanishing race", the "poorest of the poor" (Parillo, 1985, p. 217). In brief, their existence in U.S. society is not admitted.

As mentioned earlier, diasporic communities as 'others' must position themselves in American society by taking a position, by negotiating contrasting and competing cultures. In the contemporary U.S. with its diverse diasporic societies, the quest of identity becomes extremely crucial. As a crucial and universal issue, 
identity quest becomes the central theme in diasporic literature. Following and responding to the changing of American social, political and cultural nuances, the diasporic writers from each diasporic community produce diasporic literature, for example Ceremony and The Hundred Secret Senses, which are part of the genre of contemporary American fiction.

Both novels are chosen to be the material object because of the same essence which is the quest for identity embedded in the characters behavior building the storyline. Both novels have the same strong degree in delivering the émigrés and the Natives' cultural heritage and how it mingles with American cultural values. These ethnic groups are interesting and important to study because both ethnic group suffer from harsh discrimination but the Chinese have become as successful immigrants while the Natives, in contrast, are denigrating. Since each of them come from different cultural backgrounds, the construction of each identity must be different from each other and relates to their survival ability in American culture and society. Furthermore, the result of identity negotiation becomes the counter discourse of American hegemony. Due to these reasons, this research aims to explore the attempt of identity negotiation experienced by Chinese American and Native Americans as seen in Ceremony and The Hundred Secret Senses. From the perspectives of American Studies, the study of Chinese-Americans and Native American along with their literature is included in the issues of migration and diaspora. The issues of migration, diaspora and imperialism are covered by Postnational American Studies.
Since the issues of diaspora and negotiation of identity cannot be separated from each other, the study is conducted to reveal the identity negotiation experienced by Chinese Americans and Native Americans as seen in The Hundred Secret Senses and Ceremony and to find out the determining factors of identity negotiation and the survival aptitude of both communities.

\section{Methodology}

This research is qualitative research in which the interpretation is based on what "they [the researcher] see, hear, and understand" (Creswell, 2009, p. 212). This research is also inductive research under the paradigm of Post-nationalist American Studies. There are three processes in this research. The first step is collecting data. The primary data are taken from The Hundred Secret Senses and Ceremony. The secondary data is taken from internet sources, academic journals, books, and any materials related to identity negotiation. Therefore, the primary data and secondary data are read simultaneously to gain a deeper understanding of the topics. The second step is to make a categorization of the data collected based on the cultural tradition of both diasporic communities which is then connected to the context of hegemony, postcolonial studies and representation. The third step of the research is analyzing the data. To analyze and interpret the data, descriptive qualitative approach within the paradigm of constructivism is utilized. Creswell (2009) points out that "Interpretative research, with the inquirer typically involved in a sustained and intensive experience with participants... inquirers explicitly identify reflexively their 
biases, values, and personal background, such as gender, history, culture, and socioeconomic status (p. 214).

Creswell's explication affirms that descriptive qualitative approach is closely related to interpretation. This interpretation is conducted under Post-nationalist American Studies concerning on representation, U.S. hegemony and Postcolonial paradigm. The representation theories are used to examine and evaluate the diasporic literature as the primary data. The use of representation is to connect the mental evidences found in the novels and the reality of diasporic communities in U.S. society. These theories are employed collaboratively to discover and reveal the answers to research questions.

\section{Findings}

Both Chinese-Americans and Native Americans negotiate their identity by choosing, selecting, and combining cultural values they encounter as the diasporic communities in the U.S culture and society. Both novels show that the diasporic communities construct their identity through the reenactment of ethnic roots and by adapting to mainstream American cultural values. The reenactment of ethnic roots is done through sustaining spirituality, strengthening social relations and positioning diasporic women in American society. The adaptation of American cultural values is done through some process that takes more than one or two generations.

Compared to Chinese-Americans, Native Americans are more obvious in the reenactment of ethnic roots and identity. Native Americans more clearly reject
American values. For Native Americans, the reenactment of ethnic roots means reclaiming the tradition of the past which existed before the European conquest. Meanwhile Chinese-Americans are more moderate, meaning that they do not entirely reject mainstream American values. Most Chinese-Americans combine Chinese values and American values but few of them still adhere to their ethnic identity.

In sustaining spirituality, Chinese Americans only use the concept of ethnic belief and combine it with rationality. Native Americans try to return back to the essentials of their ethnic beliefs. It can be said that in the realm of spirituality, Chinese Americans are more hybrid than the Natives. This blending as a result of negotiation of identity is interesting because "It is significant that the productive capacities of this Third Space have a colonial or postcolonial provenance... but on the inscription and articulation of culture's hybridity" (Bhabha, 1994, p. 38). This is also similar with what Clifford states; that diasporic consciousness is "entirely a product of cultures and histories in collision and dialogue" (Clifford 1994, p.319).

Sustaining spirituality in both diasporic communities functions as the survival mechanism in rational society. Spirituality attached to irrationality is used to counter mainstream American values. Thus, the exposure of ghost narratives, reincarnation, storytelling about witchcraft, hunting practices, food and chants as traditional ways of healing are presented in Chinese and Native American literature to show Western perceptions about them such as that they are irrational, unscientific, 
primitive, pagan, uncivilized, and exotic. These attributes function to indicate that diasporic communities are the 'Other.' It can be said that even literature shows that there is a White domination toward the diasporic communities as pointed out by Gandhi (1998) as "Colonial textuality in Said's terms produced the 'Orient' can, thus, be read as a rehearsal for militaristic and administrative domination" (p. 143). It legalizes that the use of ethnic heritage which is undermined by the Whites is to voice out the diasporic experiences, the Western domination towards diasporic cultures and societies. It can also be said that the diasporic communities are being hegemonized by mainstream American culture and societies.

However, by sustaining spirituality, the diasporic communities are able to counter the hegemony. That is why spirituality of Chinese-Americans and Native Americans also become the mark of identity of each diasporic communities. In other words, this literature becomes the counter discourse of diasporic community. The diasporic communities as 'Other', as subaltern, as those who are thought to be submissive to Western power, in fact, are able to voice their experiences, able to resist and counter the dominant power of the West through their discourse. This is the same with what Spivak (2006) stated, "subaltern can actually speak" (p. 35).

The second means in constructing identity by reenacting ethnic roots is done through social relation. Strengthening social relations is considered important as a way of surviving in individual American society. In the social spheres, The Hundred Secret Senses and Ceremony represent that the attitudes of Chinese-Americans and
Native Americans are similar. Both of them give primary allegiance to their ethnic identity which values social embeddedness rather than individuality.

Therefore, for Chinese-Americans, it is important to keep the strong family ties to support them. As explained earlier, to strengthen family relations, the Chinese eat together and support each other. That is why, in the U.S., since the beginning of the Chinese first wave of immigration until today, there are many Chinese American organizations ranging from family, clan and kinship organizations that support each other both mentally and financially. By having family and people from the same racial and cultural background to support individuals, Chinese-Americans are more confident to live in the U.S in which individualism as White American values is considered to be a standard Gramsci (1999) stated that "the tradition of strong individual personalities in whom the vocation of work had reached its greatest intensity and strength..." (p.601). In other words, the exposure of the disagreement of divorce, mean that having good marriages and strong family ties are used to express Chinese diasporic experiences in the U.S. and to build their self-confidence so that they are able to survive in American culture and society. Besides, it marks the difference between them and White Americans so that it strengthens their identity as Chinese Americans.

It is rather different to Native Americans who do not only value family ties. Native Americans also value people relationships within certain tribal group. In the Postcolonial context, the concept of family and tribalism in Native American society is indeed considered primitive and irrational 
since for the West, every individual is given rights to do anything he/she wants to do without giving special attention to others. Moreover, the power of reason given to every individual underlies that he/she is able to do anything alone. On the contrary, in tribalism, individuals must be responsible for other members of the tribe and believe in the power of the greater spirit that guides the life of the tribe.

The function of describing such family and tribal life in the novel is to preserve Native American culture, tradition and worldview everywhere they go. It is not to hinder or forbid Native Americans from leaving the reservation to seek a better life because nowadays many of them live in the city and mingle with the white people. The purpose is to remind them that their individual existence is always attached to family, tribe and universe since it determines their survival. It emphasizes that as a Native American, a person cannot only rely on oneself. If they do so, they have lost their own existence, because they negate family, tribe and cosmic existence, whereas individual existence is part of those three. By clinging to this belief, Native Americans are able to build their self-confidence and use it as survival mechanism in American culture and society in which the stereotype of Native American inferiority and extinction is difficult to erase. In short, strengthening social relations between individual, family and tribe is the survival mechanism of Native Americans when living in individualistic America.

Hence, it can be concluded that the function of strengthening social embeddedness is as a survival mechanism in an individual society. They strengthen their social relations by maintaining their close relationships with friends, family and communities within their tribe, sub-tribe and clan. Diasporic communities are objects of prejudice and discrimination. They are seen as the 'Other' and often excluded from the mainstream American society. That is why, strengthening social relations becomes an important thing to do to support each other, spiritually, mentally and financially. It helps them a lot in living in the individual society. These social relations embody their ethnic identity, the identity of the East which differentiates it from the West. This is essentially the same with what Geertz (1960) highlighted in Religion of Java when he states, "at the ultimate level of experience there is no individuality because the more advanced one is spiritually, the more one has a genuine fellow feeling for others,... the health of society is dependent upon the right relationships between the various groups" (p. 333).

The importance of social relations is, thus, one of the central Eastern values which are strengthened by the diasporic communities in U.S. society. The Chinese give emphasis on people relations as the foundation of compassion and humanity, while Native Americans put greater stress on the wholeness of the relation between individual, family and tribe as the requirement for balancing the cosmos. These ethnic-based social relations help the diasporic communities to build selfconfidence so that they are able to compete with their White counterparts. Furthermore, it marks their difference from the Whites, in literature as well as in real life that it strengthens their identity, as Chinese- Americans or as Native Americans. Essentially, this is what is 
actually underlined by Brah (1996) that "diaspora space is the point at which boundaries of inclusion and exclusion, of belonging and of otherness, of 'us' and 'them' are contested" (p. 209). Due to the fact that both Chinese-Americans and Native Americans in the realm of social relation give primary adherence to their ethnic tradition, it can be said that principally their sense of belonging regarding social embeddedness is more related to their ethnic tradition than it is for mainstream Americans.

The third means in negotiation of identity through the reenactment of ethnic roots is by repositioning the status of diasporic women in order to pursue gender equality. Both novels are written by diasporic women. Both novels show that diasporic women are strong, hardworking, and diligent but also motherly and caring. The analysis reveals that in repositioning diasporic women's status, ChineseAmericans rejected mainstream Chinese perspective that undervalues women as weak, dependent and fragile. Instead, they chose to define their women status by claiming rare Chinese sub-ethnic values which see women's status as equal to men. On the contrary, Native Americans exhibit Native American perspectives in seeing women as respectful human beings. They see that honoring women is as important as honoring Mother Earth. The function of this reenactment is to erase the stigma that diasporic women, particularly ChineseAmerican and Native American women, are seen as weak, unable, and inferior to White men, White women and others in their own community. Both of these diasporic groups position themselves in American society by attending higher education, by participating in un-domestic spheres and having well-paying jobs.

What can be highlighted from ChineseAmerican and Native American women's status in society is that they reject patriarchal systems attached to American societies. In this regard, Chinese Americans reject mainstream Chinese perspectives about how to treat women. They select rare Chinese culture which sees women as hard workers to build their identity as Chinese-Americans who view women as warriors. In contrast, Native Americans reject the Western patriarchal system and give primary allegiance to their ethnic tradition in honoring women to construct their identity as spiritual and non-violent. Both Chinese-Americans and Native Americans reenact their perspective of women as hard workers, warriors and agents of survival and existence to build their self-confidence and to construct their identity as diasporic communities, whose women are able to stand for the communities' survival in American culture and society. The reposition of diasporic women status is to pursue equality.

The reenactment of ethnic roots through sustaining spirituality, strengthening social relations and repositioning diasporic women's status are important to building the self-confidence of diasporic communities. Having been rejected and excluded from U.S. society drives the diasporic communities to develop an inferiority complex. By reenacting ethnic root, they are able to expel the inferiority complex and restore self-confidence. In addition, ethnic roots which are considered irrational, underdeveloped, and uncivilized by the mainstream American society are used as counter discourse. Through ethnic 
roots, they strengthen their identity as diasporic communities, which differs them from the Whites. In the realm of literature, it is also used to define the identity of diasporic literature that distinguishes them with mainstream American literature. In short, ethnic roots reenactment is the reaction of diasporic communities towards American hegemony. It can also be said that it becomes the means of fighting against the hegemony through literature.

While the reenactment of ethnic root is used to define their identity as diasporic people which are different from mainstream Americans, being adapted and integrated in American society is also to construct their identity as Americans, which distinguishes them from their ancestors. In encountering mainstream American cultural values, diasporic communities do not directly and easily succeed. There is a process that must be faced by them. The initial process in encountering mainstream American cultural values is resistance. The following process of adaptation is negotiation.

The resistance towards American values is experienced by older generations of Chinese immigrants and the Native American Elders who still tightly hold on to their ethnic cultural origin. This resistance is also the embodiment of the failure in adapting to American cultural values. The later stage of adaptation is negotiation. In this process, the diasporic communities begin to realize the importance of American values as a survival mechanism. The motivation for adapting to these values cannot be separated from the history of immigrants and colonization. This shows that ChineseAmericans as immigrants have an easier time adapting. On the contrary, Native Americans as the victims of the U.S imperialism needs more time to adapt. Both novels reflect resistance and negotiation towards mainstream American cultural values.

Adapting to American values is a way of achieving financial success and equal opportunity. It is achieved through the struggle to become fluent to speak English, attending higher education institutions, enjoying material comfort and gaining equal opportunity. By being able to achieve these four things, diasporic communities become highly valued in American society. It enables them to lessen or erase their traumatic experience of being excluded and discriminated against as inferior races. Besides, it also builds their self-confidence in living in U.S. society and makes them feel that they are also part of American culture and society. The capability and strong willingness in adapting to mainstream American cultural values also develops their sense that they belong in the U.S. It marks their identity as Americans. In short, their identity is no longer stable and rooted in pure ethnicity but in a series of processes.

Both novels demonstrate the experience of diasporic communities in relation with English language as the product of American culture. If the exposure of the importance of English in The Hundred Secret Senses is used to show the acceptance of how important English is for Chinese Americans to achieve financial success, the exposure of the importance of English in Ceremony is used to describe that the ability to speak English fluently is important for Native Americans. It is also to present that finally Native Americans 
are able to negotiate the western education system.

In the realm of literature, Native American literature now uses English. There are some words that use Native American language only to give emphasis to special meanings related to cultural beliefs, but all the narratives are written in English. This finding proves what Ghandi (1998) states that "the language used by these writers' sets up, albeit inadvertently, an implicit hierarchy between imperial structure/ language/ culture on the one hand and indigenous process/practice/ experience on the other". This shows that Native Americans now are more assimilated to American culture" (p. 175). What can be underlined is that there is a hybrid identity as stated by Gilroy (1993) that the identity of diasporic people cannot be separated from their experience in the homeland as well as in the host land. This shows that all literature which is produced within the meeting of competing cultures, the culture of the dominant and the culture of the oppressed signify hybridity as described by Ashcroft et al (1989) that "all postcolonial literatures are cross-cultural" (p. 39) or "postcolonial text is always a complex and hybridised formation" (p. 110). Thus, the hybrid identity drive the diasporic communities to form a hybrid literature. The literature produced by them is part of the diaspora experience [which]... is defined, not by essence or purity, but by the recognition of a necessary heterogeneity and diversity; by a conception of "identity" which lives with and through, not despite, difference; but hybridity (Hall, 1990, p.244).

For the immigrants, the motivation in achieving success cannot be separated from their first motivation to leave their homeland in seeking for better future in the U.S. For the natives, the motivation to be more open and adaptable to American cultural values also improves their poor and miserable condition caused by U.S. imperialism. American cultural values which focus attention on achievement and struggle of the individuals become the driving force of diasporic communities to struggle for success. These values are rather different from Eastern cultural values, as the East places social status higher than individual achievement. In Eastern culture, if a person has high social status he/she inherited from his/her parents, he/she is more honored than those who struggle hard and achieve something good individually. On the contrary, a person is honored because of his/her struggle and achievement. From the analysis of the data, it can be concluded that the chance of Chinese Americans to achieve financial success is bigger than Native Americans since Native Americans tend to adhere to inner success or spiritual rather than financial success.

Financial success and material comfort cannot be separated from the history of the establishment of the U.S. itself. These two values are the embodiment of what Americans called "upward mobility" (Poter, 1954, p. 53). Every person has an equal opportunity to develop his/her potential and must struggle hard to achieve success. If a person struggles to move toward a better position, they contribute something valuable to the society. From this, it can be concluded that the American society they now belong to, will always move upward, if everyone struggles for success. It shows a sense that everyone does contribute to the development and 
progress of American society. If the country is prosperous, then the citizens will be prosperous as well. This builds a strong feeling of belonging in the U.S.

To sum up, both of diasporic communities construct their identity by also embracing mainstream American cultural values. However, there is a process in adapting to those values. The initial stage of adaptation is resistance. The depiction of resistance towards American values shows that the first generation of Chinese immigrants and the elders of Native Americans still want to preserve their cultural origin. For them, embracing American values means the destruction of their ethnic heritage. Meanwhile, the later generation of immigrants and the Native American younger generations perceive that integrating to mainstream American values is important for their survival. Being integrated into American society and adapting its customs means building their self-confidence and making them feel American. In addition, it is significant to embrace those values to revitalize their cultural heritage. Their effort in persevering their cultural heritage by embracing mainstream American values shows that they are American diasporic communities. Thus, adaptations to American cultural values are also part of identity construction since this process is always continuous and ever changing, as Hall (1990) pointed out, "Cultural identity is a matter of 'becoming' as well as of 'being'.... It is not something which already exists...they undergo constant transformation....they are subject to the continuous 'play' of history, culture, and power" (p. 225).
The strong willingness of ChineseAmericans in adapting to mainstream American cultural values often drives people to define Chinese-Americans as 'model minorities'. They become the minorities that are able to meet American life standards. In contrast, Native American emphasis on preserving and restoring their cultural values leads people to see them as the "poorest of the poor" or "the vanishing race". This definition cannot be judged as the result of identity construction of both Chinese Americans and Native Americans. If the notion of model minority or vanishing race is connected to the analysis, it can be concluded that it is only part of prejudice and discrimination. We cannot judge all Chinese Americans as model minorities or Native Americans as the vanishing race. What can be highlighted from the analysis in constructing identity through diasporic literature is that they are adapting to American culture and integrating to American society as a survival mechanism. The existence of diasporic literature also embodies the construction of diasporic identity, as Chinese or Native and as Americans.

\section{Conclusion}

To sum up, the negotiation of identity of Chinese Americans and Native Americans which is reflected in The Hundred Secret Senses and Ceremony is done by selecting, choosing or combining, competing and conflicting cultural values. It means that there are some values that they reject and some other values they accept. Both novels depict that the reenactment of ethnic roots is more exposed, while the adjustment to American values is also shown but is not emphasized. In other 
words, both Chinese Americans and Nativirah, A. (1996). Cartographies of Diaspora: American celebrate their ethnic identity. Contesting Identities. London: Routledge . However, they also appreciate and accefthang, I. (2004). The Chinese in America. New some American values. It shows that their York, NY: Penguin Group. identity is a hybrid identity which is alsohou, R. S.\& Feagin,J. R. (2014). The myth of constructed from their hybrid the model minority. ISBN consciousness. It is this diasporic identitf,lifford, J. (1994). Diasporas. Cultural a hybrid identity which makes them anthropology. 9 (3), 302-338. Retrieved survive in American society. In order to from http://www.jstor.org/stable/656365. survive, they must preserve their ethnicreswell, J. W. (2009). Research design. heritage and at the same time adjust to California, CA: SAGE Publication, Inc. American culture and society. This marlshandi. L. (1998). Postcolonial Theory: A the diasporic literature characteristic that Critical Introduction. New South Wales. makes them different from both Australia. Allen \& Unwin.

mainstream American literature and pufeertz, C. (1960). The Religion of Java. ethnic literature. It can be said that Chicago, IL. The University of Chicago diasporic literature is the symbol of Press.

diasporic existence, the sign of diasporiGilroy, P. (1993). The Black Atlantic: survival in the U.S. culture and society and Modernity and Double Consciousness. the product of cultural hybridity defining London, UK. British Library Cataloguing hybrid identity. What can be underlined Data.

from this research is that the existence offramsci, A. (1999). Selection from The Prison diasporic communities in the U.S. blurred Notebooks. London: Lawrence \& Wishart. the Americanness of America. The U.\$all, S. (1990). Cultural identity and diaspora. identity will not be as exceptional as In J. Rutherford (Ed.), Identity, before. The endless process of identity Community, Culture, Difference (pp.222negotiation of diasporic communities in 237). London: Lawrence and Wishart. the U.S. marks the viability of the PosHiggins, K. L. (2013). Financial Whirpools. nationalist Era.

Oxford: Elsevier, Inc

References

Kennedy, J. F. (2008). A nation of immigrants. ISBN 0061447544,9780061447549

Parillo, V. (1985).Stranger to these shores:

Ashcroft, Griffiths, Tiffin (Eds.). (1989) The Race and Ethnic Relations in the United Empire Writes Back: Theory and Practice States. New York, NY: Macmillan in Postcolonial Literatures, London, UK : Publishing Company.

Routledge.

Poter, D. M. (1954). People of Plenty:

Bhabha, H. (1995). The location of culture. Economic Abundance and American London: Routledge. Bowling Green State Character. Chicago, IL, University of University Press.

Chicago Press.

Bishop, A. J. (2003), Western Mathematics: Thspivak, G. C. (2006). Can the Subaltern Speak. Secret Weapon of Cultural Imperialism. In In G. G. Bill Ashcroft (Ed.), The B. Ascroft., G.Griffiths.,\& H. Tiffin (Eds.), Postcolonial Studies Reader (pp. 24-40). postcolonial studies reader, (pp. 71-76). Oxford: Routledge.

New York, NY: Taylor and Francis. 
RUBIKON Volume 3 / Number 1

February 2016

Temperly, Bradbury (Eds.). (1998).

Introduction to American Studies. London:

Longman. 